\title{
Implications of Pylodictis olivaris (Flathead Catfish) Introduction into the Delaware and Susquehanna Drainages
}

\author{
J. Jed Brown ${ }^{1,2, *}$, Joseph Perillo ${ }^{3}$, Thomas J. KwaK ${ }^{4}$, \\ AND RichaRd J. HORWITZ
}

\begin{abstract}
Pylodictis olivaris (flathead catfish) is a large, obligate carnivore native to drainages of the central United States that has been introduced widely beyond its native range. We report on the introduction of flathead catfish into the Delaware and Susquehanna River drainages, which represents the northernmost occurrences among Atlantic drainages. In the Delaware Basin, flathead catfish have been found in the Schuylkill River and the mainstem of the Delaware River. Recent sampling activities in the Schuylkill River suggest successful reproduction and establishment of a viable population there. In the Susquehanna basin, the fish has been found in the lower and central portion of the river mainstem. As in the Delaware Basin, recent sampling indicates that reproduction is occurring in the Susquehanna River. The introduction of this species has the potential to adversely affect ongoing anadromous fish restoration programs and native fish conservation efforts in the Delaware and Susquehanna basins. A cooperative effort will be required to mitigate the effects of this introduction.
\end{abstract}

\section{Introduction}

Pylodictis olivaris (Rafinesque) (flathead catfish) is a large catfish native to the southern Great Lakes and Mississippi basins, the Rio Grande, and most Gulf slope drainages (Jackson 1999, Jenkins and Burkhead 1994). Since the 1950s, it has been introduced widely into Atlantic slope drainages (Jackson 1999, Jenkins and Burkhead 1994, Quinn 1987). The flathead catfish can attain sizes greater than $1000 \mathrm{~mm}$ total length (TL), weights can exceed $50 \mathrm{~kg}$, and it is regarded by many anglers as a big-game fish (Fig. 1; Carroll and Hall 1964, Jackson 1999). It is distinguished from other large catfishes by its brownish color with mottling above, wide and flattened snout with projecting lower jaw, posterior extensions on its premaxillary tooth patch, and rounded or slightly notched (but not forked) caudal fin with a white tip on the upper lobe (except in large adults; Jenkins and Burkhead 1994, Page and Burr 1991). Life span can exceed 19 years (Carlander 1969), with recent maximum estimates of riverine fish spanning up to 28 years

${ }^{1}$ Delaware River Fisheries Coordinator's Office, US Fish and Wildlife Service, 2610 Whitehall Neck Road, Smyrna, DE 19977. ${ }^{2}$ Current address - US Fish and Wildlife Service, Central New England Fishery Resources Office, 151 Broad Street, Nashua, NH 03063. ${ }^{3}$ Philadelphia Water Department, 1500 East Hunting Park Avenue, Philadelphia, PA 19124. ${ }^{4}$ US Geological Survey, North Carolina Cooperative Fish and Wildlife Research Unit, Campus Box 7617, North Carolina State University, Raleigh, NC 27695. ${ }^{5}$ Patrick Center for Environmental Research, The Academy of Natural Sciences of Philadelphia, 1900 Benjamin Franklin Parkway, Philadelphia, PA 19103. "Corresponding author - Jed_Brown@fws.gov. 
(Nash and Irwin 1999). Males mature in 3-4 years and females mature in 45 years (Minckley and Deacon 1959, Munger et al. 1994). Juveniles feed primarily on aquatic insects, but when they reach approximately $100 \mathrm{~mm}$ or greater, they become almost exclusively piscivorous, with large crustaceans also consumed (Etnier and Starnes 1993, Jackson 1999).

The flathead catfish inhabits medium to large rivers, lakes, and reservoirs (Etnier and Starnes 1993). It is typically less active during daylight hours and is closely associated with structure such as brush piles, undercut banks, and log jams (Etnier and Starnes 1993). Young are found in shallow areas in streams and gradually shift their habitat use to deeper waters with age (Jackson 1999). Flathead catfish is predominantly a nocturnal feeder. Some large individuals are believed to feed by lying motionless on the bottom with an open mouth, until cover-seeking prey swim into its mouth (Trautman 1957). However, most flathead catfish actively feed by lunging and seizing prey (Minckley and Deacon 1959).

The rapid dispersal and population growth rates of introduced flathead catfish, along with their obligate carnivorous food habits, have caused concern among fish scientists and management agencies. Flathead catfish have become established in most water bodies where they have been introduced

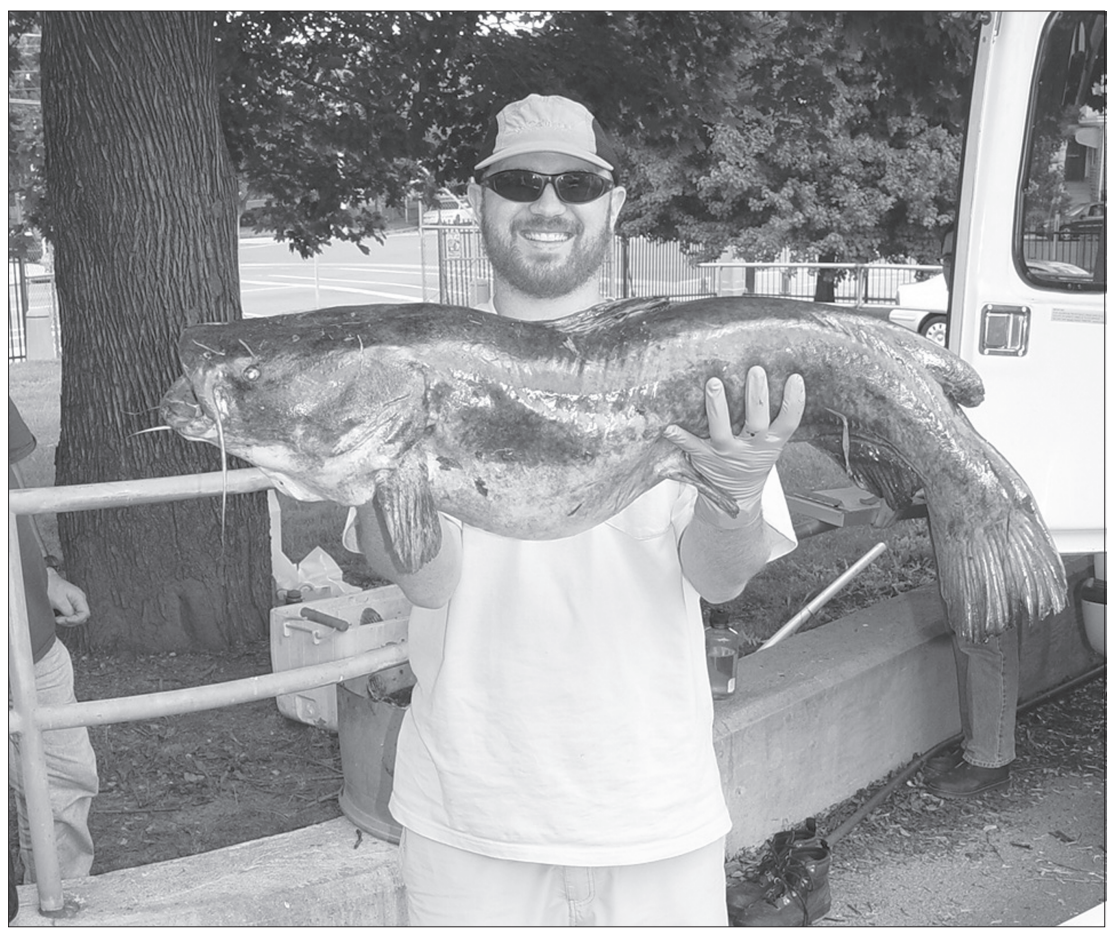

Figure 1. Introduced flathead catfish have rapidly become one of the largest predators in the Schulykill River. Here, J. Perillo holds a female flathead catfish measuring $985 \mathrm{~mm}$ total length and wighing $15.2 \mathrm{~kg}$., removed from the Fairmound fish ladder, Philadelphia, PA, during routine maintenance in August 2004 (photo by W. Richardson). 
(Fuller et al. 1999). The United States Fish and Wildlife Service has placed flathead catfish as its highest priority among invasive animal species in southeastern United States (Memorandum dated 3 November 1999). The adverse ecological effects of introduced flathead catfish on native fish populations have been widespread, and they are exemplified by the case of the Cape Fear River introduction. In North Carolina's Cape Fear River, Guier et al. (1981) found that within 15 years of a single point introduction of 11 adult flathead catfish, the species spread over a $230-\mathrm{km}$ reach of river, became the dominant predator in the river, and severely reduced native fish species. Fifteen years after introduction, flathead catfish constituted $10.5 \%$ of total fish numbers and $64.7 \%$ of total fish biomass of Cape Fear River samples (Guier et al. 1981). Feeding studies showed that flathead catfish fed primarily on Ameiurus spp. (bullheads); however, when available, they consumed substantial numbers of anadromous Alosinae (Ashley and Buff 1987, Guier et al. 1981, Kwak et al. 2004). Bullhead population densities have declined following flathead catfish introduction into rivers, and populations of Lepomis auritus (Linnaeus) (redbreast sunfish), popular for recreational fishing, have also declined in rivers where they coexist with introduced flathead catfish (Ashley and Rachels 1998, Guier et al. 1981). Such declines have been shown in other river systems in the southeastern United States (Thomas 1993), and although the evidence is correlative, it suggests direct negative effects by flathead catfish predation. Food-web simulation modeling further supports the hypothesis that direct predation by introduced flathead catfish suppresses native freshwater resident and anadromous fish populations in coastal rivers (Kwak et al. 2004, Pine 2003).

The Delaware and Susquehanna Rivers are two large coastal river systems of the mid-Atlantic United States. The Delaware River is approximately $531 \mathrm{~km}$ long and drains $35,065 \mathrm{~km}^{2}$, which includes portions of the states of Delaware, Pennsylvania, New Jersey, and New York. The mainstem of the Delaware River is undammed. The Schuylkill River, the largest tributary of the Delaware, has eight dams on the lower $130 \mathrm{~km}$ and enters the Delaware River at Philadelphia, PA. The Susquehanna River is approximately $715 \mathrm{~km}$ long and drains $71,224 \mathrm{~km}^{2}$, which includes portions of the states of Pennsylvania, New York, and Maryland. The mainstem of the Susquehanna is regulated by four large hydropower dams on the lower 90 river kilometers. We report here on the introduction of the flathead catfish into these two large river systems and the associated implications for native fish conservation and restoration efforts.

\section{Methods}

There are currently no ongoing, large-scale research surveys directed solely at detecting the flathead catfish in these two river systems. The majority of data from the Delaware system were gathered by biologists of the Philadelphia Water Department (PWD) and Academy of Natural Sciences of Philadelphia (ANSP), who began to encounter flathead catfish in 1999 while conducting routine cleaning of a fish ladder on the Fairmount 
Dam (rkm 14, Fig. 2), the farthest downstream dam on the Schuylkill River. Electrofishing surveys conducted by the PWD, ANSP, and the Pennsylvania Fish and Boat Commission (PAFBC) provided additional data for the Delaware system. Other data were provided by the New Jersey Department of Environmental Protection (NJDEP), from environmental consulting companies conducting gillnetting on the Delaware River, and from recreational anglers and guides who reported their catches to state agencies. The data from the Susquehanna River were obtained from observations at the Conowingo (rkm 16) and Holtwood dams (rkm 39), from electrofishing surveys conducted by environmental consultants, and from recreational anglers who reported their catches to the PAFBC. Two specimens of flathead catfish from the Schuylkill River, ANSP 179499 (prepared as a skeleton) and ANSP 180634 (preserved as a whole fish) have been accessioned into the permanent fish collection at ANSP as vouchers.

\section{Results}

\section{Delaware Basin}

Biologists from the PWD and ANSP captured a total of 150 flathead catfish in the lower Schuylkill River from 1999-2003 (Table 1). The majority of these fish were collected using dip nets at the Fairmount Fishway when the fishway was being drained for maintenance (123). The remainder were captured by electrofishing in the vicinity of the Fairmount Dam (14), Vincent Dam (rkm 72) (3), 0.3 km downstream of Black Rock Dam (rkm 54)(7), and

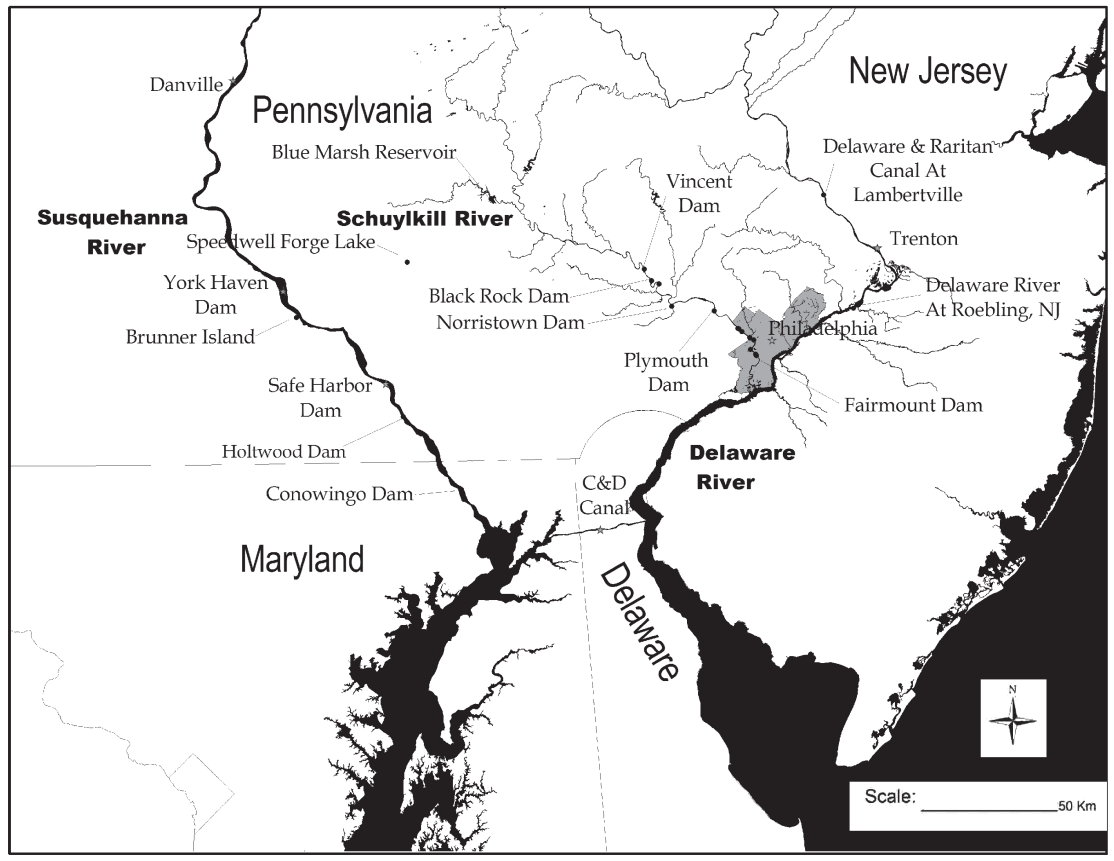

Figure 2. Locations in the Delaware and Susquehanna drainages with confirmed flathead catfish reports as of 2004. 
Plymouth Dam (rkm 33)(1); one fish was found dead in a drinking-water supply reservoir in the lower Schuylkill River (Belmont Basin, Philadelphia, PA, discharges to water treatment facility); and one fish was discovered alive and tied to a retaining wall in Manayunk Canal, which runs parallel to the Schuylkill River for $2.7 \mathrm{~km}$ in Philadelphia. The number of fish captures or confirmed observations steadily increased among years (Table 1); however, these annual collections are not based on equal sampling effort and do not necessarily indicate population size increases. During targeted boat electrofishing for flathead catfish in 2003, ANSP caught three flathead catfish downstream of the Vincent Dam, seven along the shore about $0.3 \mathrm{~km}$ downstream of the Black Rock Dam, and one at the base of the Plymouth Dam in Norristown. Video monitoring of fish passage at Fairmount Fishway in 2004 has revealed frequent upstream and downstream movement of flathead catfish. No clear temporal pattern in mean fish size (length or weight) was evident among years. In 2003, 80 fish were sexed via direct examination of gonads. Forty males and 40 females were observed. Of the 40 females, 12 (30\%) were gravid, and 4 (10\%) collected in July contained spent ovaries.

In 1997, PAFBC first identified a flathead catfish population in the Blue Marsh Reservoir, an impoundment on Tulpehocken Creek, which enters the Schuylkill River at rkm 123 near Reading, Berks County, PA, while conducting routine electrofishing (PAFBC 2002). Since 1997, there have been several additional angler catches from the Blue Marsh Reservoir reported to the PAFBC. Additionally, unconfirmed angler catches from the Schuylkill River reported to PAFBC included 18 flathead catfish caught from 2001 to 2003. These fish were caught in a short reach of the river from the pool above the Black Rock Dam (rkm 59) to $7 \mathrm{~km}$ downstream of the dam. In October 2004, PAFBC conducted an electrofishing survey at rkm 41 in the

Table 1. Total number of flathead catfish observed in the Schuylkill River, Delaware Basin, by the Philadelphia Water Department and the Philadelphia Academy of Natural Sciences. Mean total length, weight, and standard error (SE) of the mean and ranges are reported for a subset of the fish observed $(n=$ sample size).

\begin{tabular}{|c|c|c|c|c|c|c|c|}
\hline \multirow[b]{2}{*}{ Year } & \multirow{2}{*}{$\begin{array}{l}\text { Total fish } \\
\text { observed }\end{array}$} & \multicolumn{3}{|c|}{ Total length $(\mathrm{mm})$} & \multicolumn{3}{|c|}{ Wet weight $(\mathrm{g})$} \\
\hline & & Mean & SE & Range & Mean & SE & Range \\
\hline 1999 & 1 & $\begin{array}{l}515.0 \\
(n=1)\end{array}$ & & & & & \\
\hline 2000 & 10 & $\begin{array}{c}642.0 \\
(n=10)\end{array}$ & 48.1 & $(460-1000)$ & $\begin{array}{c}4294 \\
(n=10)\end{array}$ & 1192 & $(1250-14,050)$ \\
\hline 2001 & 11 & $\begin{array}{c}574.2 \\
(n=11)\end{array}$ & 39.2 & $(392-767)$ & $\begin{array}{c}2050 \\
(n=8)\end{array}$ & 470 & $(745-5000)$ \\
\hline 2002 & 28 & $\begin{array}{c}423.7 \\
(n=25)\end{array}$ & 31.9 & $(113-740)$ & $\begin{array}{c}1620 \\
(n=17)\end{array}$ & 370 & $(345-6000)$ \\
\hline 2003 total & 100 & $\begin{array}{c}553.3 \\
(n=100)\end{array}$ & 13.5 & $(62-900)$ & $\begin{array}{c}2663 \\
(n=93)\end{array}$ & 174 & $(195-12,500)$ \\
\hline 2003 males & 40 & $\begin{array}{c}545.0 \\
(n=40)\end{array}$ & 14.9 & $(407-900)$ & $\begin{array}{c}2289 \\
(n=40)\end{array}$ & 307 & $(700-12,500)$ \\
\hline 2003 females & 40 & $\begin{array}{c}617.0 \\
(n=40)\end{array}$ & 14.4 & $(389-775)$ & $\begin{array}{c}3141 \\
(n=40)\end{array}$ & 244 & ( 950-7100) \\
\hline Total & 150 & $\begin{array}{c}536.3 \\
(n=147)\end{array}$ & 13.5 & $(62-1000)$ & $\begin{array}{c}2614 \\
(n=128)\end{array}$ & 186 & $(195-14,050)$ \\
\hline
\end{tabular}


Schuylkill (2.5 km upstream of the Norristown dam) and captured three flathead catfish (total length ca. 300, 375, $825 \mathrm{~mm}$ ) and observed one other not captured. No flathead catfish has been collected from the tidal portion of the Schuylkill River downstream of Fairmount Dam. Concerted sampling for flathead catfish has not been conducted in the upper Schuylkill River, so the upstream extent of the species is not known.

In the mainstem Delaware River, three flathead catfish have been caught by gillnet since 2001 (J. O’Herron, O’Herron Biological and Environmental Consulting, pers. comm.). In 2004, a 240-mm fish was collected in the Delaware and Raritan Canal at Lambertville, NJ (M. Boriek, NJDEP, pers. comm.); the canal has direct connection to the Delaware River at Bulls Island, NJ (rkm 251). A recreational fishing guide reported the capture of three flathead catfish in the mainstem Delaware River near Trenton, NJ in 2004 (M. Boriek, pers. comm.). Additionally, flathead catfish have been reported by anglers from the Springton Reservoir, a drinking-water supply reservoir in Delaware County, PA, that discharges into the mainstem Delaware River. There have been other unconfirmed reports of flathead catfish captures by anglers, although some were misidentifications (M. Boriek, pers. comm.).

\section{Susquehanna Basin}

The first report of flathead catfish in the Susquehanna Basin occurred in 1991, when PAFBC captured one individual while electrofishing in Speedwell Forge Lake, a small impoundment on a tributary to Cocalico Creek (M. Kaufmann, PAFBC, pers. comm.). There were no other reports of flathead catfish in the Susquehanna Basin until recreational anglers reported capturing them in 2002. The PAFBC maintains a database of recreational angler catches (voluntarily reported by anglers to the PAFBC) of flathead catfish in the Susquehanna River, and 29 flathead catfish were reported caught in 2002, 2003, and 2004 from the Holtwood Dam pool (rkm 39) to Danville, PA (rkm 198). These fish ranged in length from approximately $250-750 \mathrm{~mm}$ TL.

Operators of the Conowingo Dam's West fish lift (elevator), the most downstream dam on the Susquehanna River (rkm 16), took seven flathead catfish from about $450 \mathrm{~g}$ to $>$ 4,500 g during May 13-28, 2004. None were seen at Conowingo's East lift viewing window, but four were viewed passing Holtwood Dam (rkm 39). Susquehanna River Anadromous Fish Restoration Cooperative annual reports for 2001-2003 reported no flathead catfish at any of the Susquehanna River fish passage facilities in those years (SRAFRC 2002-2004). In September 2004, an environmental consultant conducting shoreline electrofishing near Brunner Island (rkm 87) captured three flathead catfish. The smallest of the three fish measured $74 \mathrm{~mm} \mathrm{TL}$, and the other two measured 205 mm (T. Euston, Normandeau Associates, pers. comm.).

\section{Discussion}

\section{Population establishment}

The collection of gravid females, small juveniles, and a range of size classes in the Schuylkill River clearly documents that natural reproduction is 
occurring and that a viable flathead catfish population has been established. Similarly, the presence of juveniles in the Susquehanna River also indicates a viable population. This finding of viable flathead catfish populations in as few as seven years after the species was first detected in a system, is in accord with previous observations farther south. Initial flathead catfish stockings of 11 fish in the Cape Fear River, North Carolina, and 12 fish in a reservoir of the lower Potomac River drainage in Virginia, quickly established viable populations, and populations were similarly established via reservoir stockings in the Roanoke River system in Virginia (Guier et al. 1981, Jenkins and Burkhead 1994).

The mode of flathead catfish introduction into the Delaware and Susquehanna systems remains unknown, but we suggest three scenarios that might account for their presence in these systems: (1) accidental stocking, (2) intentional introduction by anglers, and (3) migration. Firstly, in both basins, Ictalurus punctatus (Rafinesque) (channel catfish) were stocked into reservoirs by the PAFBC to provide sportfishing. These channel catfish fingerlings were provided by public hatcheries that also produced flathead catfish fingerlings, and thus it is possible that flathead catfish fingerlings may have been inadvertently mixed with the channel catfish fingerlings and accidentally stocked into reservoirs adjacent to these rivers (M. Kaufman, pers. comm). Once introduced in reservoirs, fish could easily disperse to the river channel. Secondly, it is possible that the fish were intentionally introduced by anglers, who wanted the opportunity to catch a large sport fish close to their residences. Thirdly, flathead catfish may have colonized these two river systems by migration. Flathead catfish may have migrated downstream from the Potomac River, where they were first introduced in the 1960s, and then moved northward up Chesapeake Bay. From northern Chesapeake Bay, fish may have either entered the Susquehanna River or swam through the Chesapeake and Delaware Canal into the Delaware River. Similarly, flathead catfish from the Delaware Basin may have migrated through the Chesapeake and Delaware Canal into the Chesapeake Bay and into the Susquehanna River.

Direct introduction by anglers appears to be the most likely flathead catfish introduction scenario. Managers from the hatcheries that supplied the channel catfish fingerlings believed that it is very unlikely that flathead catfish were mixed in with the channel catfish (A. Brandenburg, Little Grassy Fish Hatchery, Makanda, IL, and J. Hawkinson (ret.), Senecaville State Fish Hatchery, Senecaville, $\mathrm{OH}$, pers. comm.). It is possible that flathead catfish may have migrated between river systems. Although flathead catfish are considered a freshwater species, they have been collected in brackish waters near river mouths with salinity $>2$ ppt (C. Oakley, North Carolina Wildlife Resources Commission, unpubl. data), and laboratory exposures defined the median lethal salinity (96 hours) for juvenile flathead catfish as high as $14.5 \mathrm{ppt}$ (Bringolf et al. 2005). The salinity of the Delaware River at the Chesapeake and Delaware Canal ranges from about 10 ppt during drought to 0 ppt during spring floods (Smullen et al. 1983), suggesting that flathead catfish migration between the Delaware and Chesapeake Basins would not be restricted by salinity. 
These findings support the notion that flathead catfish may disperse among river systems via migration, especially during periods of flooding. However, it is unlikely that flathead catfish would have invaded these two river systems by migration. Firstly, this would require an extremely long-range migration. Secondly, in order for flathead catfish to enter the Susquehanna River, it would have required that they successfully passed undetected through the Conowingo East lift and the Holtwood lifts (both operated in fish passage mode only for about 40-60 days/year and only since 1997). All fish using these devices are visually counted and identified and flathead catfish were not detected. They were not seen in the Conowingo West lift (trap) until 2004, and all fish passing there are handled and identified.

\section{Dispersal within river systems}

Once established, flathead catfish populations may disperse rapidly throughout a river system. The flathead catfish in its native range has been thought to be sedentary and several traditional tagging and radio-telemetry studies have supported that generalization (Dames and Coon 1989, Funk 1955, Skains and Jackson 1993). Conversely, recent research in rivers on native flathead catfish in Missouri (Vokoun 2003) and introduced populations in North Carolina (Kwak et al. 2004) clearly demonstrate that the fish can be highly mobile, with movements exceeding $45 \mathrm{rkm}$ within a month and home-range estimates up to $69 \mathrm{rkm}$. It appears that such migration patterns may be related to reproductive seasons and river flow patterns. These new findings of high mobility in the species may explain the rapid expansion of introduced populations. Thus, dispersal of the flathead catfish populations throughout the Delaware and Susquehanna basins should be expected, compelling management planning at the drainage-basin scale.

The mainstem of the Delaware River remains undammed. Thus, any fish in the mainstem of the Delaware River could migrate up and downstream unimpeded for several hundred kilometers. The Schuylkill River, the largest tributary of the Delaware, has eight dams in its lower $130 \mathrm{~km}$. It is unlikely that the three most upstream of these would impede catfish movement since they are partially breached. Flathead catfish have been caught upstream of all of the other five dams, suggesting translocation by anglers. There is currently no physical barrier to upstream movement until the Kernsville Dam at rkm 161. By 2007, we anticipate that all of the dams in the lower 130 $\mathrm{km}$ will either be removed or will have fish passage facilities installed, further facilitating flathead catfish dispersal. The dispersal of flathead catfish despite the presence of dams is not a unique occurrence. Flathead catfish in the Cape Fear River system of North Carolina have dispersed throughout the drainage basin over time, appearing upstream of several dams that should function as barriers to upstream movement, similarly suggesting that these fish were translocated by anglers. Such findings suggest that, regardless of dam occurrence, flathead catfish will likely disperse throughout much of the Delaware and Susquehanna Rivers.

In the Susquehanna Basin, fish passages were completed at all lower river hydroelectric dams between 1997-2000, and construction is underway 
or planned at the state-owned inflatable dam at Sunbury, PA, at Williamsport and Lock Haven on the West Branch, and at Binghamton, NY, on the North Branch and Elmira, NY, on the Chemung River. Thus, flathead catfish will soon have access to almost $1000 \mathrm{~km}$ of the Susquehanna mainstem and its major tributaries.

\section{Impacts on imperiled species}

Due to its ability to reach large sizes and highly piscivorous feeding habits, the flathead catfish has the potential to negatively affect ongoing anadromous fish restoration efforts in the Delaware and Susquehanna basins. Historically, the Delaware River supported the largest Alosa sapidissima (Wilson) (American shad) fishery on the Atlantic coast (Chittenden 1974). Overfishing and water quality problems led to serious depletion of this population through the 1970s. In the late 1960s and 1970s, water quality began to improve and American shad began to return to the river in larger numbers. The improvement in water quality, combined with the commitment of the state of Pennsylvania to provide fish passage, led to the initiation of an American shad restoration stocking program in the Schuylkill River by the PAFBC. This effort to restore the American shad run might be jeopardized by the introduction of the flathead catfish. Two studies of North Carolina coastal rivers have found that flathead catfish actively feed on juvenile and adult anadromous shad (Ashley and Buff 1987, Kwak et al. 2004). Further, food-web modeling in an Atlantic coastal river system suggested that an established flathead catfish population could reduce juvenile anadromous shad biomass by about 25\% (Kwak et al. 2004, Pine 2003).

Similarly by direct predation, introduced flathead catfish in these two rivers could negatively affect threatened and endangered fish populations. In the mainstem of the Delaware, Acipenser oxyrinchus Mitchell (Atlantic sturgeon) and Acipenser brevirostrum Lesueur (shortnose sturgeon) populations are imperiled. Predation by flathead catfish on juvenile sturgeon could prove detrimental for their survival, and the benthic co-occurrence of these sturgeons with the flathead catfish suggests cause for concern.

The upper Delaware River supports an economically-important tailwater fishery for nonnative trout (Salmonidae). A 1996 study found that angling for trout in this system resulted in $\$ 17.69$ million in local revenues and generated approximately $\$ 30$ million in local economic activity for Delaware County, NY (Maharaj et al. 1998). Invasion of the upper Delaware River by flathead catfish could negatively affect this important fishery.

In the Susquehanna River, four large hydropower dams were constructed in the early 1900s on the lower $90 \mathrm{~km}$ of river, blocking American shad from their upstream spawning migration (St. Pierre 2003). In the early 1970s, a cooperative American shad restoration program was initiated. This effort entailed restoration stocking and fishway construction. By the year 2000, fish passage was provided at the four major dams, so that currently American shad can migrate past the York Haven Dam at rkm 90. To date, this program has cost over $\$ 75$ million. The introduction of the flathead catfish could result in negative effects on the continued success of this restoration program. 


\section{Management implications}

Introduced populations of flathead catfish pose a challenge to fisheries managers, because of conflicting objectives among constituents. First, this species is a highly prized sport and food fish. Anglers appreciate the fish as a formidable-fighting and good-eating game fish, and recreational fishing for introduced flathead catfish has provided economic benefits to rural communities, especially near water bodies where competitive fishing tournaments take place. Thus, there has been variable resistance to eradication of the fish in other systems (Weller and Geihsler 1999) and already, there appears to be resistance to eradication in the Delaware Basin (M. Kaufmann, pers. comm.). However, one survey suggested that among methods to reduce introduced flathead catfish population numbers, anglers supported recreational and commercial fishing (Weller and Geihsler 1999). Unlike most other introduced invasive aquatic species, which are vilified by the popular press and the public, the flathead catfish retains appeal as an invasive charismatic fauna.

The Pennsylvania Department of Environmental Protection (PADEP) conducted contaminant analyses of flathead catfish tissue from the lower Schuylkill River at the Fairmount Dam. They found polychlorinated biphenyl (PCB) tissue concentrations of $1 \mathrm{mg} / \mathrm{g}$ wet weight and chromium concentrations of $0.655 \mathrm{mg} / \mathrm{g}$ wet weight. These results compelled a consumption advisory of one meal per month due to PCB contamination (M. Boyer, PADEP, pers. comm.).

Thus, education and outreach efforts related to flathead catfish reduction may be a challenging endeavor and could focus on increasing fish harvest, within constraints of consumption advisories due to fish contaminant loads. Other management efforts to be considered may include mechanisms to limit dispersal among sub-basins and to other drainage basins (e.g., public education, transport regulations, enforcement), creative means to increase fish harvest by the public (e.g., public education, assessment of commercial fishing), and study of other removal methods (e.g., trapping, netting, electrofishing, hand grappling, bounties). Complete eradication of the flathead catfish from these two drainages may be an unrealistic goal. Mitigation of the effects of this fish introduction will require additional information from focused research and a cooperative effort by resource management agencies, private conservation organizations, and the public to protect native fishes.

\section{Acknowledgments}

The authors wish to thank a number of people who have shared information on the flathead catfish or otherwise participated in studies reported here, including Mike Kaufmann and Bryan Chikotas (PAFBC), Mark Boriek (NJDEP), John O'Herron (O'Herron Biological and Environmental Consulting), Robert Ford (PWD), Lance Butler (PWD), Paul Overbeck (ANSP), Kevin O'Donnell (University of Missouri), Terry Euston (Normandeau Associates), John Teeter (Monell Chemical Senses Center), Bill Pine and Scott Waters (North Carolina Cooperative Fish and Wildlife Research Unit), Jason Vokoun (University of Connecticut), Mike Boyer (PADEP), Richard St. Pierre (USFWS), and Matthew Jones (Delaware State University). Ann Faulds 
(Pennsylvania Sea Grant) has been instrumental in bringing together researchers studying the spread of flathead catfish in Pennsylvania. This project was financed, in part, through a Federal Coastal Zone Management Grant, administered by PADEP. Funding was provided by the National Oceanic and Atmospheric Administration (NOAA), United States Department of Commerce, under Award Number NA03NOS4190098. The views expressed herein are those of the author(s) and do not necessarily reflect those of the US Department of Commerce, NOAA, the PADEP, nor any of their sub-agencies.

\section{Literature Cited}

Ashley, K.W., and B. Buff. 1987. Food habits of flathead catfish in the Cape Fear River, North Carolina. Proceedings of the Annual Conference Southeastern Association of Fish and Wildlife Agencies 41:93-99.

Ashley, K.W., and R.T. Rachels. 1998. Changes in redbreast sunfish population characteristics in the Black and Lumber rivers, North Carolina, 1994-1997. Proceedings of the Annual Conference Southeastern Association of Fish and Wildlife Agencies 52:29-38.

Bringolf, R.B., T.J. Kwak, W.G. Cope, and M.S. Larimore. 2005. Salinity tolerance of flathead catfish: Implications for dispersal of introduced populations. Transactions of the American Fisheries Society 134:927-936.

Carlander, K.D. 1969. Handbook of Freshwater Fishery Biology. Volume 1. Life History Data on Freshwater Fishes of the United States and Canada, Exclusive of the Perciformes. Iowa State University Press, Ames, IA. 752 pp.

Carroll, B.B., and G.E. Hall. 1964. Growth of catfish in Norris Reservoir, Tennessee. Journal of the Tennessee Academy of Science 39:86-91.

Chittenden, M.E. 1974. Trends in the abundance of American shad Alosa sapidissima in the Delaware River Basin. Chesapeake Science 15:96-103.

Dames, H.R., and T.G. Coon. 1989. Movements of channel and flathead catfish between the Missouri River and a tributary, Perche Creek. Transactions of the American Fisheries Society 118:670-679.

Etnier, D.A., and W.C. Starnes. 1993. The Fishes of Tennessee. University of Tennessee Press, Knoxville, TN. 681 pp.

Fuller, P.L., L.G. Nico, and J.D. Williams. 1999. Nonindigenous Fishes Introduced into Inland Waters of the United States. American Fisheries Society Special Publication 27, American Fisheries Society, Bethesda, MD. 613 pp.

Funk, J.L. 1955. Movement of stream fishes in Missouri. Transactions of the American Fisheries Society 85:39-57.

Guier, C.R., L.E. Nichols, and R.T. Rachels. 1981. Biological investigation of flathead catfish in the Cape Fear River. Proceedings of the Annual Conference Southeastern Association of Fish and Wildlife Agencies 35:607-621.

Jackson, D.C. 1999. Flathead catfish: Biology, fisheries, and management. Pp. 2335, In E.R. Irwin, W.A. Hubert, C.F. Rabeni, H.L. Schramm, Jr., and T. Coon (Eds.). Catfish 2000: Proceedings of the International Ictalurid Symposium. American Fisheries Society Symposium 24, American Fisheries Society, Bethesda, MD. 516 pp.

Jenkins, R.E., and N.M. Burkhead. 1994. Freshwater Fishes of Virginia. American Fisheries Society, Bethesda, MD. 1079 pp.

Kwak, T.J., W.E. Pine, D.S. Waters, J.A. Rice, J.E. Hightower, and R.L. Noble. 2004. Population dynamics and ecology of introduced flathead catfish: Phase 1 final report. Federal Aid in Sport Fish Restoration Project F-68, Study Number 1, Final Report, Submitted to Division of Inland Fisheries, North Carolina Wildlife Resources Commission, Raleigh, NC. 217 pp. 
Maharaj, V., J. McGurrin, and J. Carpenter. 1998. The economic impact of trout fishing on the Delaware River Tailwaters in New York. Report prepared for the American Sportsfishing Assocation and Trout Unlimited, Washington, DC. 34 pp.

Minckley, W.L., and J.E. Deacon. 1959. Biology of the flathead catfish in Kansas. Transactions of the American Fisheries Society 88:344-355.

Munger, C.R., G.R. Wilde, and B.J. Follis. 1994. Flathead catfish age and size at maturation in Texas. North American Journal of Fisheries Management 14:403-408.

Nash, M.K., and E.R. Irwin. 1999. Use of otoliths versus pectoral spines for aging adult flathead catfish. Pp. 309-316, In E.R. Irwin, W.A. Hubert, C.F. Rabeni, H.L. Schramm, Jr., and T. Coon (Eds.). Catfish 2000: Proceedings of the International Ictalurid Symposium. American Fisheries Society Symposium 24, American Fisheries Society, Bethesda, MD. 516 pp.

Page, L.M., and B.M Burr. 1991. A Field Guide to Freshwater Fishes of North America North of Mexico. Houghton Mifflin Company, Boston, MA. 432 pp.

Pennsylvania Fish and Boat Commission (PAFBC). 2002. Information paper. Flathead catfish Pylodictis olivaris. Available at: http://sites.state.pa.us/PA_Exec/ Fish_Boat/flathinf.htm. [Accessed September 7, 2004].

Pine III, W.E. 2003. Population ecology of introduced flathead catfish. Ph.D. Dissertation. North Carolina State University, Raleigh, NC. 183 pp.

Quinn, S.P. 1987. Stomach contents of flathead catfish in the Flint River, Georgia. Proceedings of the Annual Conference Southeastern Association of Fish and Wildlife Agencies 41:85-92.

Skains, J.A., and D.C. Jackson. 1993. Linear ranges of large flathead catfish in two Mississippi streams. Proceedings of the Annual Conference Southeastern Association of Fish and Wildlife Agencies 47:539-546.

Smullen, J.T., J.H. Sharp, R.W. Garvine, and H.H. Haskin. 1983. River flow and salinity. Pp. 9-25, In J.H Sharp (Ed.). The Delaware Estuary: Research as Background for Estuary Management and Development. Delaware River and Bay Authority Report. Lewes, DE. 340 pp.

St. Pierre, R.A. 2003. A case history: American shad restoration on the Susquehanna River. Pp. 315-321, In K.E. Limburg and J.R. Waldman (Eds.). Biodiversity, Status, and Conservation of the World's Shads. American Fisheries Society Symposium 35, American Fisheries Society, Bethesda, MD. 369 pp.

Susquehanna River Anadromous Fish Restoration Cooperative (SRAFRC). 20022004. Restoration of American shad to the Susquehanna River. Annual Progress Reports for 2001-2003. US Fish and Wildlife Service, Harrisburg, PA.

Thomas, M.E. 1993. Monitoring the effects of introduced flathead catfish on sport fish populations in the Altamaha River, Georgia. Proceedings of the Annual Conference Southeastern Association of Fish and Wildlife Agencies 47:531-538.

Trautman, M.B. 1957. The Fishes of Ohio. Ohio State University Press, Columbus, OH. 683 pp.

Vokoun, J.C. 2003. Movement and habitat use of flathead catfish (Pylodictis olivaris) in two Missouri interior streams. Ph.D. Dissertation. University of Missouri, Columbia, MO. 186 pp.

Weller, R.R., and M.R. Geihsler. 1999. Angler attitudes concerning the management of the introduced flathead catfish in the Altamaha River system, Georgia. Pp. 435-442, In E.R. Irwin, W.A. Hubert, C.F. Rabeni, H.L. Schramm, Jr., and T. Coon (Eds.). Catfish 2000: Proceedings of the International Ictalurid Symposium. American Fisheries Society Symposium 24, American Fisheries Society, Bethesda, MD. 516 pp. 